\title{
Editor's Introduction: Limitations of the Tang-Song Transition Theory
}

\author{
Sun Qi 孫齊 \\ Advanced Department of Confucian Studies, Shandong University, \\ Jinan, Shandong, China \\ sun_qi@foxmail.com
}

The Tang [618-907] and Song [96o-1279] periods enjoy special historical status among the ancient Chinese dynasties. In the Ming Xiaoling 明孝陵 mausoleum of the founding emperor of the Ming dynasty [1368-1644] Zhu Yuanzhang 朱元璋 [r. 1368-1398], this fact was highlighted in the inscription by the Qing dynasty's [1616-1911] Kangxi emperor 康熙 [r. 1661-1722]: “[the Great Ming was] governed to a level of prosperity even greater than that of the Tang and Song" [zhilong Tang-Song 治隆唐宋]. The Tang was considered a glorious cosmopolitan empire, while the Song was deemed the pinnacle of Chinese civilization. However, the transition between the two periods was anything but smooth, and scholars have long recognized fundamental differences between them. Among the many historical explanations, the Tang-Song transition theory proposed in the early twentieth century by Naitō Torajirō 內藤虎次郎 [18661934]—commonly known as Naitō Konan 內藤湖南—is the best known and the most influential.

The Tang-Song transition theory was widely influential in the study of Chinese history by Japanese scholars, particularly during debates over periodization that took place in the mid-twentieth century. After the 1970s, the theory became a source of debate in the Song history research community in the United States. Although it had long been known to Chinese scholars, the topic suddenly become the subject of fierce contention at the turn of the twenty-first century for many reasons, such as the massive translation of sinological works from outside China, the declining popularity of the Marxist historiographical paradigm, and the efforts of Chinese scholars to avoid the trend toward trivial topics. Over the past twenty years the Tang-Song transition theory has undoubtedly become one of the most familiar historical concepts to Chinese scholars. As a result, an increasing number of scholars have begun to examine the misuse of the concept and even question its explanatory validity. 
Four articles in this issue of $\mathrm{JOCH}$ represent the recent reflections of Chinese scholars on this topic. The article "Dispelling the Myth of the "Tang-Song Transition Theory," by Yang Jiping 楊際平, presents a critical analysis of the basic conclusions and main points of Naitō's hypothesis and argues that the grounds for his arguments are problematic, being "just an abstract set of principles for discussion that are based on Eurocentrism." In his article, "Time to Turn the Page in Tang and Song History Studies: Exploring the Tang-Song Transformation Theory from Multiple Perspectives," Li Huarui 李華瑞 presents a commentary on previous scholarship, in which he argues that the theory has become outdated and that it has done little to advance the study of Tang-Song history, concluding that it is now time to "turn the page on history written with an old paradigm and justified by old values." "A Historical Study of Political System Reform in the Tang and Song Dynasties," Wang Huayu's 王化雨 article, reflects on the many shortcomings of the Tang-Song transition theory through the lens of political history and proposes some directions for future research. Mou Fasong's 牟發松 article, “A Discussion of Several Issues Concerning the "Tang-Song Transition," presents a concise review of Naitō's theory.

In sum, Chinese scholars have gradually come to a consensus that the Tang-Song transition theory should be reconsidered. As for how long it will take to build a consensus around a new paradigm, that remains to be seen.

Translated by Carl Gene Fordham 